\title{
Phenological variation in leaf chemistry of Nothofagus macrocarpa in relation to Ormiscodes sp. growth and survival
}

\author{
Variación fenológica de la composición química foliar de Nothofagus macrocarpa \\ en relación al crecimiento y sobrevivencia de Ormiscodes sp.
}

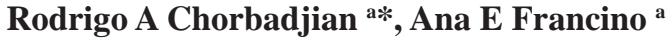

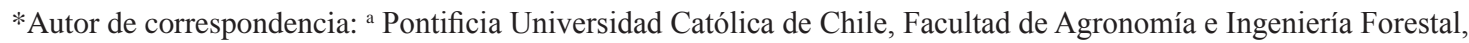 \\ Departamento de Ciencias Vegetales, Santiago, Chile, rchorba@uc.cl
}

\begin{abstract}
SUMMARY
Host phenology can affect leaf feeding insects through changes in foliar chemical-physical traits. Santiago's southern beeches (Nothofagus macrocarpa) form relic forest patches at the northernmost distribution range for the entire genus in America. Outbreaks of leaf feeding species in the genus Ormiscodes (Lepidoptera: Saturniidae) have the potential to defoliate extensive areas of several Nothofagus species; yet the mechanisms regulating their population dynamics remain largely unexplored. A univoltine Ormiscodes species that consumes $N$. macrocarpa foliage from mid October to November was studied. To investigate how host phenological variation in chemical traits relates with insect performance, larval growth and survival were determined at the time of natural hatch and on neonates whose emergence was delayed for 21, 30, and 79 days. Each time, foliar nitrogen and total phenolics concentration were quantified. Delaying egg hatch relative to plant phenology resulted in decreased larval growth and survival. Larval growth was more sensitive to changes in host quality than larval survival. The reduction of insect growth was strongly correlated with the concentration of foliar nitrogen, but not with total phenolics. These results indicate that the timing of larval emergence and foliar nitrogen concentration are key traits that may play a role in the population dynamics of this insect.
\end{abstract}

Key words: phenological window, life-history strategy, host-plant quality.

\section{RESUMEN}

La fenología de la planta hospedera puede afectar a insectos defoliadores a través de cambios en rasgos físico-químicos de las hojas. Roble de Santiago (Nothofagus macrocarpa) forma bosques relictos al extremo norte de la distribución del género en América, constituyéndose en un ecosistema único. Ciclos poblacionales eruptivos de especies del género Ormiscodes (Lepidoptera: Saturniidae) tienen el potencial de defoliar vastas áreas de Nothofagus spp., pero los mecanismos reguladores de su dinámica poblacional han sido poco estudiados. Se estudió una especie univoltina del género Ormiscodes que consume follaje de $N$. macrocarpa desde mediados de octubre a noviembre. Se evaluó la sobrevivencia y crecimiento larval al momento de su emergencia natural y al retrasarla 21, 30, y 79 días. Se cuantificó la concentración foliar de nitrógeno total y fenoles totales. Como resultado, se determinó que la sobrevivencia y crecimiento larval decrecieron a medida que su emergencia se retrasó. El crecimiento larval fue más sensible a cambios en la calidad del follaje en comparación con su sobrevivencia. La disminución del crecimiento y sobrevivencia de los insectos se correlacionó significativamente con la concentración de nitrógeno foliar, pero no con la concentración de fenoles totales. Estos resultados indican que el momento de emergencia de las larvas, y la concentración foliar de nitrógeno total son importantes factores que podrían tener un rol en la dinámica poblacional de este insecto.

Palabras clave: ventana fenológica, historia de vida, calidad de hospedero.

\section{INTRODUCTION}

The genus Nothofagus Blume (Nothofagaceae) (southern beeches) is a group of forest trees found exclusively in the southern hemisphere (South America, New Guinea, New Caledonia, New Zealand, Australia, and Tasmania) that has been often used to investigate historical biogeography, vegetation patterns, and diversity patterns of its fauna (Ramírez 1987, McQuillan 1992, Veblen et al. 1996, Quiroz et al. 1999, Russell et al. 2000, 2004, Lavandero et al. 2009). Deciduous species of Nothofagus are abun- dant in the temperate rainforests of Chile and Argentina (Wilcox 1996, Veblen et al. 1996, del Fierro 1998). One of these species is the Roble de Santiago (Nothofagus macrocarpa (A.DC.) F. M. Vázquez et R. A. Rodr.) (Vázquez and Rodríguez 1999), which is endemic to Chile and forms relic forest patches at the northernmost distribution range of this genus in America (Ormazábal and Benoit 1987).

South American Nothofagus species are host to a great diversity of insect fauna, yet little is known about their biology, life-history strategies, and chemically-mediated interaction with their hosts. Insect species in the genus Or- 
miscodes Blanchard (Lepidoptera: Saturniidae) are of particular interest due to their potential to reach outbreak population levels and defoliate extensive areas of Nothofagus trees (Bauerle et al. 1997, Lanfranco et al. 2001, Angulo et al. 2004, Baldini and Alvarado 2008, Paritsis et al. 2010). Nine Ormiscodes species have been recognized in a recent publication by Angulo et al. (2004). Some of these species such as $O$. cinnamomea Feisthamel and especially O. amphimone (Fabricius) have received more attention due to reported outbreaks (Baldini and Alvarado 2008, Paritsis et al. 2009, 2010, Paritsis and Veblen 2011), but there are still many unsolved questions regarding other species. In this study, one yet undescribed species (Angulo et al. 2004) that feeds on N. macrocarpa in the patchy forests North of Santiago (Cerro el Roble at $\approx 32^{\circ} 56^{\prime}$ S. L.) was used. Reference adult specimens are maintained in the insect collection of the School of Agriculture and Forestry Engineering at Pontificia Universidad Católica de Chile (Santiago, Chile). Similarly to what happened with the other Ormiscodes species, we observed that their larvae feed gregariously on newly developed foliage during spring (mid Oct. - Nov.). Its life cycle is univoltine and adult emergence occurs in autumn when groups of 100200 eggs are laid in a ring pattern attached to the most distal branch tips of the host, where they remain latent until the following spring.

Spring feeders that rely on the leaves of deciduous trees face a dilemma, which is that larval emergence from hibernating eggs must be coordinated with the timing of leaf emergence, as it can be critical for larval survival (reviewed by van Asch and Visser 2007). Emerging too early may result in starvation if switching host is not an option. On the contrary, individuals emerging too late generally encounter a food resource of reduced quality. Investigating this dilemma has resulted in fecund research lines addressing questions regarding host quantitative and/or qualitative traits regulating the population dynamics of many herbivores, including native insects and forest invasive pests. Nonetheless, this subject has not been investigated on any Lepidoptera species feeding on Nothofagus spp. trees.

Phenological variation in host quality provides a framework to study resource-based constraints underlying life history strategies of herbivore insects (Feeny 1970, Mattson et al. 1982, Ayres and MacLean 1987, Lawrence et al. 1997, van Asch and Visser 2007). The phenological window of host susceptibility hypothesis (Feeny 1976) predicts that herbivorous insects feed on plants during specific periods of the season when host quality is most suitable for them. Phenological variation in host quality for the herbivore is characterized by a combination of nutrients and secondary metabolites that may underlie proximal mechanisms of feeding habit specialization (Mattson et al. 1982). This framework was used to investigate natural phenological variation in foliar chemical composition of Nothofagus macrocarpa and its potential role mediating the performance of its defoliator insect, Ormiscodes sp.
Previous studies on Nothofagus spp. leaf chemistry indicate that foliar nitrogen concentration decreases as the phenology of N. obliqua (Mirb.) Oerst., N. pumilio (Poepp. et Endl.) Krasser (Hevia et al. 1999), and N. moorei (F. Muell.) Krasser (Brunt et al. 2006) advances. Concentration of total phenolics has been shown to decrease (Brunt et al. 2006) or to increase as N. moorei leaves aged (Lowman and Box 1983); a tree species that is not present in South America. Other studies found environmental effects on foliar content of total phenolics by comparing xeric and mesic site effects on $N$. pumilio (Paritsis and Veblen 2010); a species that grows at the southernmost distribution range for the genus in America. Additionally, volatile terpenoids have been shown to affect host location behavior of specialized aphid species (Quiroz et al. 1999).

The objective of this study is to investigate the effect of delayed insect phenology in relation to plant phenology to increase understanding of plant chemical traits that could be related with the performance of this defoliator insect. Our working hypothesis is that Ormiscodes sp. lifehistory strategy is to synchronize larval emergence with host's developmental stages most susceptible to insect attack, a plant stage that could be described on a chemical basis.

\section{METHODS}

Plant material and phenology. Six year-old trees of $N$. macrocarpa $(1.5 \mathrm{~m}$ high and $2.5 \mathrm{~cm}$ basal trunk diameter) were maintained in $20 \mathrm{~L}$ containers in the experimental plant growth unit of the School of Agriculture and Forestry Engineering, Santiago, Chile. Trees were acclimated to ambient conditions of the experimental unit for one growth season previous to the experiments conducted the following spring in 2010. A Raschel mesh (20\% shade screen) was used during the first months of acclimation to reduce stress. Plant phenology was quantified by measuring the length of one representative shoot and its leaves for each experimental tree. Shoot and leaf lengths were added to create a continuous phenological variable for each tree, as reported for other plant species (Sampson et al. 2003).

Host-insect natural synchrony. During the acclimation growth season, a group of insects was allowed to phenologically synchronize with the experimental trees. This provided neonates for the treatment used to quantify larval performance during normal host-insect phenological synchrony. To do this, during autumn of 2009, a group of 40 adults were liberated into large cages $(2 \times 2 \times 2 \mathrm{~m})$ containing a separate set of six trees more than those used for the experiments. These adults were obtained from field collected groups of larvae that were reared until adult emergence in the lab. Eggs laid on those trees were allowed to naturally undergo diapause. The following spring, egg hatch started on 28 September 2010. 
Insect feeding assays. Four feeding assays were conducted during the spring of 2010; September 28, October 19 and 28 , and December 16. These dates corresponded with 0,21, 30 , and 79 days of delayed hatch respectively. All assays were conducted using Ormiscodes sp. neonates (newly hatched first-instar), as larval developmental stage could be an experimental confounding factor when testing for changes in host quality. Hibernating eggs were collected from the Cerro el Roble locality the first weeks of September 2010 , and stored in a cold chamber at $0{ }^{\circ} \mathrm{C}$ to maintain them latent until needed. Previous to each bioassay, about 200 eggs were transferred to $20{ }^{\circ} \mathrm{C}$ to induce hatch. Cold storage did not have an apparent effect on neonates, as they look vital, fed on foliage, and most of them survived for at least one week. For each assay, groups of 10 neonates (because they feed gregariously) were fed with foliage from each experimental tree. Offspring of at least three different females were pooled to minimize potential maternal effects over larval responses. Every other day, fresh leaves were collected from standardized branch tips and provided ad libitum to the larvae. Feeding assays were conducted in $15 \mathrm{~cm}$ petri dishes with a humidified plaster layer to keep moisture. Larval growth and survival were evaluated after seven days and once again after two weeks (except on the treatment of 79 days of hatch delay). Feeding assays were conducted in a growth chamber at $20^{\circ} \mathrm{C}$. During these two weeks, most of the surviving larvae completed their $2^{\text {nd }}$ instar. Survival corresponded to the number of living larvae after seven and fourteen days, and growth of surviving larvae was calculated as the difference between mean final and mean initial mass (to the nearest $0.01 \mathrm{mg}$ ).

Chemical analyses. Foliage from each tree was collected three days after initiating each feeding assay. Foliage was frozen with liquid nitrogen and then stored at $-20^{\circ} \mathrm{C}$ until processed. Leaves were lyophilized for $72 \mathrm{~h}$ at $-45^{\circ} \mathrm{C}$, then ground in a mill (Tempra: micro plant grinding machine) to pass through a mesh with $1 \mathrm{~mm}$ openings, and stored in a desiccator. Total nitrogen content was analyzed in an atomic absorption spectrometer (Truspec CHN analyzer) on $120 \mathrm{mg}$ subsamples. Total phenolics content was analyzed by spectrophotometry using the Folin-Ciocalteu method (Ainsworth and Gillespie 2007). In preliminary experiments, extraction times of $4,8,12,24,48$, or $72 \mathrm{~h}$ using either methanol or distilled water as the solvent were investigated, concluding that neither the solvent used $(P=0.174)$, the extraction time $(P=0.078)$, nor the interaction between both factors $(P=0.382)$ affected the results. Therefore, $50 \mathrm{mg}$ of ground dried leaves were extracted using $1 \mathrm{~mL}$ distilled water for $24 \mathrm{~h}$ at $5{ }^{\circ} \mathrm{C}$. Following centrifugation, $30 \mu \mathrm{L}$ of supernatant were diluted with $470 \mu \mathrm{L}$ distilled water. Then, $50 \mu \mathrm{L}$ Folin-Ciocalteu reagent, $150 \mu \mathrm{L} 20 \%$ $\mathrm{Na}_{2} \mathrm{CO}_{3}$ solution, and $750 \mu \mathrm{L}$ distilled water were added to a $50 \mu \mathrm{l}$ aliquot of the diluted extract. For total phenolics quantification, UV absorbance spectra of actual samples relative to tannic acid were recorded at $765 \mathrm{~nm}$ on a spec- trophotometer (Shimadzu, UV1700 Pharmaspec). Results are reported as percent tannic acid equivalents per dry foliar mass.

Data analyses. The experimental unit corresponded to a group of ten larvae feeding on one tree per date, with five replicated trees. All variables were tested for ANOVA assumptions and transformed as needed. Significant differences among means were detected using Fisher's protected LSD test. Linear correlation coefficients to quantify relationships between dependent variables were calculated using MINITAB 15 statistical software.

\section{RESULTS}

Insect growth and survival in response to delayed hatch. Delaying insect hatch relative to natural plant phenology had a great effect on neonate growth both after one $(P<0.001)$ and two weeks of feeding $(P<0.001)$. During the first week, the effect of delaying egg hatch on larval growth was $81.5 \%, 92.6 \%$, and $97.2 \%$ growth reduction when emergence was delayed in 21,30 , and 79 days, respectively. Most insects survived after completing the first week of the feeding assays, with a small reduction in their survival when hatch was delayed 30 or 79 days $(P=0.064)$. After the second week, survival was significantly reduced only when hatch was delayed for 30 days $(P=0.002)$ (figure 1). Thus, during the first two weeks of insect development, larval survival was less sensitive to phenological changes in foliar quality than larval growth.

Insect performance regarding phenological variation in foliar chemistry. Foliar concentration of nitrogen decreased $36 \%$, but the concentration of total phenolics remained constant during the progression of plant development. Most of the variation determined for insect growth was explained by foliar nitrogen concentration $(r=-0.77, P<0.001 ; r=$ $-0.79, P=0.001$, for the first and second weeks respectively), but total phenolics concentration were not statistically correlated with insect growth $(\mathrm{r}=0.10, P=0.693$; $\mathrm{r}$ $=0.38, P=0.196$, for the first and second weeks respectively). Insect survival was not correlated with either nitrogen or total phenolics concentration $(r<0.33, P>0.172)$.

On each experimental tree, plant phenology was quantified adding the lengths of one shoot and that of its leaves as they elongated. The variable used to quantify plant phenology was useful to quantify plant phenological variation only between the first and the second feeding assays, because it did not change after tree growth stopped (table 1), even though their phenological development continued.

\section{DISCUSSION}

It was determined that delaying insect hatch relative to host phenology had a great negative effect on insect growth and to a lesser degree on larval survival. This result is con- 

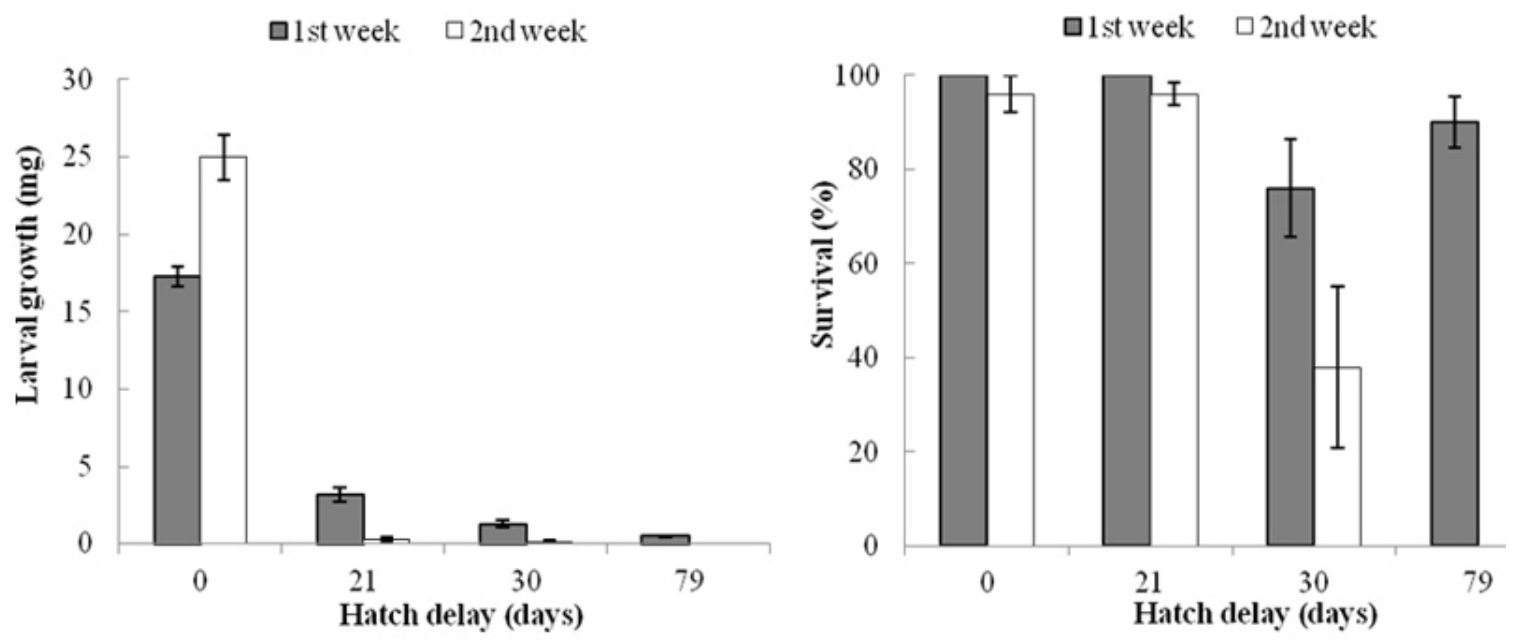

Figure 1. Growth and survival of Ormiscodes sp. neonates in response to delayed hatch. Neonates were fed with fresh foliage for a total of two weeks. Bars are means \pm 1 SEM.

Crecimiento y sobrevivencia de Ormiscodes sp. en respuesta al retraso de su emergencia. Neonatos fueron alimentados con follaje fresco durante dos semanas. Barras representan promedios \pm 1 error estándar.

Table 1. Foliar chemical traits of Nothofagus macrocarpa as phenology advanced.

Concentración de compuestos químicos en follaje de Nothofagus macrocarpa a medida que avanza su fenología.

\begin{tabular}{cccc}
\hline \multirow{2}{*}{$\begin{array}{c}\text { Days relative to natural } \\
\text { insect hatch }\end{array}$} & $\begin{array}{c}\text { Plant phenology } \\
\text { (shoot + leaves length }(\mathrm{mm}))\end{array}$ & \multicolumn{2}{c}{ Foliar chemistry } \\
\cline { 3 - 4 } & $29 \pm 13.9$ & Nitrogen (\% DW) & Total phenolics (\% DW) \\
21 & $132 \pm 19.6$ & $4.5 \pm 0.3 \mathrm{a}$ & $6.3 \pm 0.38$ \\
30 & $136 \pm 19.6$ & $2.9 \pm 0.1 \mathrm{~b}$ & $5.2 \pm 0.57$ \\
79 & $138 \pm 19.2$ & $2.9 \pm 0.4 \mathrm{~b}$ & $5.3 \pm 0.46$ \\
$P$ value & $<0.001$ & $2.1 \pm 0.2 \quad \mathrm{c}$ & $6.3 \pm 1.10$ \\
\hline
\end{tabular}

sistent with the phenological window of host susceptibility hypothesis (Feeny 1976), which predicts that herbivorous insects feed on plants during specific periods of the season when host quality becomes most suitable for them. Thus, Ormiscodes sp. larval emergence occurs when foliar quality of $N$. macrocarpa provides a suitable food source for this insect.

Phenological changes in foliar chemical composition create chemically-defined niches that are utilized by herbivores. This phenological window of host susceptibility to the herbivore is characterized by a suit of foliar chemical and physical traits, called the vector-trait space (Mattson et al. 1982). Newly developing foliage generally has soft tissues rich in nitrogen and water. As this foliage develops, cell developmental processes usually result in decreased nutrient and increased secondary metabolite concentrations (Mattson 1980). This pattern results in young leaves being more suitable for some insect herbivores, especially for spring feeding Lepidoptera species (Feeny 1970, 1976, Cates 1980, Ayres and MacLean 1987, Lawrence et al. 1997, van Asch and Visser 2007).
As the phenology of $N$. macrocarpa advanced, the concentration of nitrogen decreased sharply, a result that is consistent with reports on other related species, such as $N$. obliqua, N. pumilio (Hevia et al. 1999), and N. moorei (Brunt et al. 2006). In contrast, the concentration of total phenolics did not change as the phenology of N. macrocarpa advanced. As such, correlation analyses indicate that nitrogen concentration explained most of the variation detected in Ormiscodes sp. neonate growth and survival, which is concordant with the well documented role of nitrogen on the performance of numerous insect species (Mattson 1980, Herms 2002).

Studies on how host quality affects Ormiscodes spp. caterpillars that feed on Nothofagus foliage are scarce. Paritsis and Veblen (2010) investigated the variation generated by both xeric and mesic site conditions on $N$. pumilio foliar qualitative traits and related them to O. amphimone performance. These authors concluded that higher concentration of foliar phenolics was not related to negative effects on $O$. amphimone. Concordantly, no correlation between foliar 
phenolics concentration and insect growth or survival was determined in this study. Perhaps Ormiscodes sp. larvae are able to metabolize plant secondary chemicals. In preliminary determinations, we found that as much as $20 \%$ of larval frass may be phenolics compounds, which is about three times higher than on $N$. macrocarpa foliage used to feed the larvae. However, a strong correlation between total nitrogen concentration and insect growth was determined in this study, a divergence with results reported by Paritsis and Veblen (2010); which could be explained by differences in the species or perhaps due to the low variability that they encounter in foliar nitrogen content among their study sites. Clearly, more studies measuring host quality effects on Ormiscodes spp. performance are needed to increase understanding of bottom-up mechanisms regulating the population dynamics of this and other similar species that defoliate Nothofagus spp. forests.

Insect-host phenological asynchrony has been shown to be a critical component affecting insect population growth parameters in many systems (Ayres and MacLean 1987, Lawrence et al. 1997, van Asch and Visser 2007). Environmental factors that have a differential effect on host plant phenology compared with insect phenology may shift this tight relationship and affect insect population growth. South American Ormiscodes species have been reported to reach outbreak population cycles and defoliate extensive Nothofagus spp. forest areas (Bauerle et al. 1997, Lanfranco et al. 2001, Baldini and Alvarado 2008, Paritsis et al. 2009, 2010, Paritsis and Veblen 2011). Interestingly, climatic changes during the last 150 years have been related with increased frequency of severe defoliation events in southern Patagonia (Paritsis and Veblen 2011). Even though selective pressures other than host quality, such as natural enemies (Paritsis et al. 2012), may interact with host qualitative traits to regulate insect population dynamics (Parry et al. 1998, Hunter and Elkinton 2000), this study contributes to improve understanding of bottom-up effects on Ormiscodes sp. interaction with N. macrocarpa.

\section{ACKNOWLEDGEMENTS}

Research funds were provided by Fondo Nacional de Desarrollo Científico y Tecnológico FONDECYT inicio 11090237, año 2009. We thank M. Kogan, C. Alister, and M. Araya (Centro de Investigación Agrícola y Ambiental, Universidad de Viña del Mar) for facilitating access to the CHN dry combustion analyzer (LECO), and Nataly Jara and Sebastian Castro for assistance conducting chemical analyses.

\section{REFERENCES}

Ainsworth EA, KM Gillespie. 2007. Estimation of total phenolic content and other oxidation substrates in plant tissues using Folin-Ciocalteu reagent. Nature Protocols 2: 875-877.
Angulo AO, C Lemaire, TS Olivares. 2004. Catálogo crítico e ilustrado de las especies de la familia Saturniidae en Chile (Lepidoptera: Saturniidae). Gayana 68(1): 20-42.

Ayres MP, SF MacLean. 1987. Development of birch leaves and growth energetics of Epirrita autumnata (Geometridae). Ecology 68(3): 558-568.

Baldini A, A Alvarado. 2008. Manual de plagas y enfermedades del bosque nativo en Chile. Santiago, Chile. Editora e Imprenta Maval Ltda.

Bauerle P, P Rutherford, D Lanfranco. 1997. Defoliadores de Roble (Nothofagus obliqua), Raulí (N. alpina), Coigüe ( $N$. dombeyi) y Lenga (N. pumilio). Bosque 18(2): 97-107.

Brunt C, J Read, GD Sanson. 2006. Changes in resource concentration and defence during leaf development in a toughleaved (Nothofagus moorei) and soft-leaved (Toona ciliata) species. Oecologia 148: 583-592.

Cates RG. 1980. Feeding patterns of monophagous, oligophagous, and polyphagous insect herbivores: The effect of resource abundance and plant chemistry. Oecologia 46(1): 22-31.

del Fierro P. 1998. Experiencia silvicultural del bosque nativo de Chile. Recopilación de antecedentes para 57 especies arbóreas y evaluación de prácticas silviculturales. Santiago, Chile. Corporación Nacional Forestal, CONAF. 420 p.

Feeny P. 1970. Seasonal changes in oak leaf tannins and nutrients as a cause of spring feeding by winter moth caterpillars. Ecology 51: 565-581.

Feeny P. 1976. Plant apparency and chemical defense. Recent Advances in Phytochemisty 10: 1-40.

Herms DA. 2002. Effects of fertilization on insect resistance of woody ornamental plants: reassessing an entrenched paradigm. Environmental Entomology 31(6): 923-933.

Hevia F, ML Minolletti, KLM Decker, REJ Boerner. 1999. Foliar nitrogen and phosphorus dynamics of three Chilean Nothofagus (Fagaceae) species in relation to leaf lifespan. American Journal of Botany 86(3): 447-455.

Hunter AF, JS Elkinton. 2000. Effects of synchrony with host plant on populations of spring- feeding Lepidopteran. Ecology 81(5): 1248-1261.

Lanfranco D, E Rojas, R Ríos, C Ruiz. 2001. Insect defoliators of Nothofagus obliqua (Roble) in south Chile: Two years monitoring species and their damage. In Liebhold AM, ML McManus, IS Otvos, SLC Fosbroke eds. Proceedings: Integrated management and dynamics of forest defoliating insects; 1999 August 15-19; Victoria, BC. Gen. Tech. Rep. NE-277. Newtown Square, PA; U.S. Department of Agriculture, Forest Service, Northeastern Research Station. p. 91-103.

Lavandero B, A Labra, CC Ramírez, HM Niemeyer, E FuentesContreras. 2009. Species richness of herbivorous insects on Nothofagus trees in South America and New Zealand: The importance of chemical attributes of the host. Basic and Applied Ecology 10: 10-18.

Lawrence RK, WJ Mattson, RA Haack. 1997. White spruce and the spruce budworm: defining the phenological window of susceptibility. The Canadian Entomologist 129: 291-318.

Lowman MD, JD Box. 1983. Variation in leaf toughness and phenolic content among five species of Australian rain forest trees. Australian Journal of Ecology 8: 17-25.

Mattson WJ. 1980. Herbivory in relation to plant nitrogen. Annual Review of Ecology and Systematics 11: 119-161. 
Mattson WJ, N Lorimer, RA Leary 1982. Role of plant variability (trait vector dynamics and diversity) in plant/herbivore interactions. In Heybroek HM, BR Stephan, K von Weissenberg eds. Resistance to diseases and pests in forest trees. Wageningen, The Netherlands. Pudoc. p. 295-303.

McQuillan PB. 1992. Nothofagus (Fagaceae) and its invertebrate fauna - an overview and preliminary synthesis. Biological Journal of the Linnean Society 49: 317-354.

Ormazábal CP, IC Benoit. 1987. El estado de conservación del género Nothofagus en Chile. Bosque 8(2): 109-120.

Paritsis J, TT Veblen, T Kitzberger. 2009 Assessing dendroecological methods to reconstruct defoliator outbreaks on Nothofagus pumilio in northwestern Patagonia, Argentina. Canadian Journal of Forest Research 39: 1617-1629.

Paritsis J, TT Veblen. 2010. Temperature and foliage quality affect performance of the outbreak defoliator Ormiscodes amphimone (F.) (Lepidoptera: Saturniidae) in northwestern Patagonia, Argentina. Revista Chilena de Historia Natural 83: 593-603.

Paritsis J, M Elgueta, C Quintero, TT Veblen. 2010. New hostplant records for the defoliator Ormiscodes amphimone (Fabricius) (Lepidoptera: Saturniidae). Neotropical Entomology 39: 1048-1050.

Paritsis J, TT Veblen. 2011. Dendroecological analysis of defoliator outbreaks on Nothofagus pumilio and their relation to climate variability in the Patagonian Andes. Global Change Biology 17(1): 239-253.

Paritsis J, C Quintero, T Kitzberger, TT Veblen. 2012. Mortality of the outbreak defoliator Ormiscodes amphimone (Lepidoptera: Saturniidae) caused by natural enemies in northwestern Patagonia, Argentina. Revista Chilena de Historia Natural 85: 113-122.

Parry D, JR Spencer, WJA Volney. 1998. Budbreak phenology and natural enemies mediate survival of first-instar tent caterpillar (Lepidoptera: Lasiocampidae). Environmental Entomology 27(6): 1368-1374.

Quiroz A, E Fuentes-Contreras, CC Ramírez, GB Russell, HM Niemeyer. 1999. Host-plant chemicals and distribution of Neuquenaphis on Nothofagus. Journal of Chemical Ecology 25(5): 1043-1054.

Ramírez C. 1987. El género Nothofagus y su importancia en Chile. Bosque 8(2): 71-76.

Russell GB, WS Bowers, V Keesing, HM Niemeyer, T Sevenet, S Vasanthaverni, SD Wratten. 2000. Patterns of bioactivity and herbivory on Nothofagus species from Chile and New Zealand. Journal of Chemical Ecology 26(1): 41-56.

Russell GB, EH Faúndez, HM Niemeyer. 2004. Selection of Nothofagus host trees by the aphids Neuquenaphis staryi and Neuquenaphis edwardsi. Journal of Chemical Ecology 30(11): 2231-2241.

Sampson DA, TJ Albaugh, KH Johnsen, HL Allen, SJ Zarnoch. 2003. Monthly leaf area index estimates from point-in-time measurements and needle phenology for Pinus taeda. Canadian Journal of Forest Research 33: 2477-2490.

van Asch M, ME Visser. 2007. Phenology of forest caterpillars and their host trees: The importance of synchrony. Annual Review of Entomology 52: 37-55.

Vázquez FM, RA Rodríguez. 1999. A new subspecies and two new combinations of Nothofagus Blume (Nothofagaceae) from Chile. Botanical Journal of the Linnean Society 129: 75-83.

Veblen TT, RS Hill, J Read. 1996. The ecology and biogeography of Nothofagus forests. New Haven, USA. Yale University Press. 403 p.

Wilcox K. 1996. Chile's native forests, a conservation legacy. Redway, California, USA. Ancient Forest International. 148 p. 